joint, knees of middle and of hind legs and the tips of their tibiae, honey yellow. Wings hyaline, the veins brown, the marginal vein linear but rather stout, twice as long as the stigmal, the post-marginal slender, a little longer than the stigmal. The flagellum is about three and a half times as long as the scape; the funicle 5 -jointed, the first joint the longest, not quite twice as long as thick, the following joints imperceptibly shortening, submoniliform; club 3-jointed, a little longer than the first two funicular joints united, the joints closely conjoined. Thorax as in $E$. diastrophi. Abdomen conically pointed, subcompressed, nearly one-half longer than the head and thorax united, smooth and pol- ished, except segments 6,7 and 9 which are finely shagreened from some microscopic punctures and bearded with white hairs.

8. Length $2.5 \mathrm{~mm}$. Agrees with the $q$ in color, but the funicular joints are incised and pedicellate at tips, the thickened portion being furnished with two whorls of long white hairs, some of which are as long as the joints, the latter very gradually decreasing in length; the club is as long as the first funicular joint, but slenderer; while the body of the abdomen is small, compressed and as viewed from the side triangular in outline attached to the metathorax by a long petiole which is finely sculptured or shagreened and nearly as long as the body of the abdomen.

\title{
PRICKLY LEAF-GALL OF RHODITES TUMIDUS ON ROSA FENDLERI.
}

\author{
BY C. H. TYLER TOWNSEND, BROWNSVILLE, TEXAS.
}

A few miles to the north of Ojo Caliento, on the Hot Springs reserva. tion, in Socorro County, New Mexico, some spherical prickly galls were found in bunches on the leaves of a wild rose, June $\mathrm{r} 8, \mathrm{r} 892$. They were the size of very large peas, reddish and greenish, and covered with prickles One of these galls that was opened Dec. 13, 1892, contained a whitish live hymenopterous pupa, which was somewhat active. This was the pupa of the gall-maker, Rhodites tumidus Bass.

Description of gall.-Diameter 3 to $9 \mathrm{~mm}$. Usual size, 6 to $8 \mathrm{~mm}$. Globular, or subglobular, covered with prickles on upper half, prickles mostly directed upward especially the more superior ones which are from I to It $\mathrm{mm}$. long, those on sides much shorter. Color brick-reddish above, and pea-green below, indicating the surface that has been exposed to the sun and that which has been sheltered therefrom. Growing in bunches, from 2 to 10 in a bunch, rarely singly. Borne always on upper surface of leaf, sometimes three on the same very small leaf which is thus almost obliterated, sometimes borne on petiole of leaf, often double. Gall containing a single large perfectly round cavity, lined with a very thin greenish lining, walls $1 \frac{1}{5} \mathrm{~mm}$. thick in gall of $8 \mathrm{~mm}$. external diameter, leaving cavity about $5 \frac{3}{5} \mathrm{~mm}$. in diameter. Walls porous, minutely cellular, a cross section appearing finely reticulate under lens, the lining of cavity sharing this appearance. The walls average $\mathrm{I} \mathrm{mm}$. in thickness. Each gall contains but a single occupant. The double ones never communicate inside. The gall-fly emerges by a circular hole gnawed in one side of the gall about $1 \frac{1}{2} \mathrm{~mm}$. in diameter.

Described from $3^{8}$ galls. From two of these galls, two gall-flies had 
emerged and died, being discovered April 2, 1893. On April 3, 1893, all of the remaining galls were opened Every one contained an insect, either as adult, pupa, or in one case (that of the smallest gall only $3 \mathrm{~mm}$. in diameter) a small shrivelled larva. The occupants were as follows : Dead adults (including the two that had emerged), I 2 ; live adults, 6 ; pupae, I8; larva, I. The pupa usually bears the cast larval skin attached dorsally to the anal extremity.
The gall-fly is 4 to $4 \frac{1}{2} \mathrm{~mm}$. long. The whole insect is black, except the abdomen and legs which are orange-red. Wings subhyaline, shaded with fuscous. It is a notable fact that no sign of a parasite was discovered in all of these galls.

I am indebted to Mr. Wm. H. Ashmead for identifying the Rhodites. It is a very pretty species. The abdomen changes to a dark but very highly polished brown in dried specimens.

\section{THE BOMBYLID GENUS ACREOTRICHUS IN AMERICA.}

BY D. W. COQUilletT, WASHINGTON, D. C.

For several years past the writer has enjoyed the privilege of examining many interesting forms of Diptera taken by Prof. O. B. Johnson in various parts of the state of Washington, and several of these have been made known from time to time in our various entomological journals. Among a recent sending is a single specimen belonging to the Bombylid genus Acreotrichus of Macquart, heretofore known only from Australia. It is closely related to the genus Phthiria, differing in the structure of the antennae and in the densely hairy face. The species is as follows :

Acreotrichus americanus n. $\mathrm{sp} . \delta$. Black, including the palpi and knob of halters, only the stem of the latter is yellow. Eyes contiguous, frontal triangle and face gray pollinose, face and underside of head densely long black pilose. Antennae slightly longer than the head, first joint twice as long but not wider than the second, the latter as broad as long, both densely long black pilose; third joint slightly over twice as long as the first, at its base narrower than the second joint, continuing slender nearly to the middle, then rather suddenly expanding to nearly twice its former width, the greatest expansion being on its upper side, then tapering quite suddenly to the tip which is blunt; a short, blunt-pointed style on the upper side of this joint a short distance before the apex; on the upper edge of the expanded portion of this joint are five black bristly hairs, each nearly half as long as the joint itself. Proboscis as long as the head and thorax taken together, the labella very narrow; palpi filiform, twofifths as long as the proboscis. Thorax velvety, the front corners, sides and pleura gray pollinose, its pile black; scutellum velvety, densely black pilose. Abdomen velvety, its pile light yellowish. Wings hyaline, stigma yellow, second submarginal cell not appendiculate, small crossvein scarcely beyond the middle of the discal cell. Length $7 \mathrm{~mm}$. Washington. A single specimen captured April 4, I894 (O. B. Johnson). 

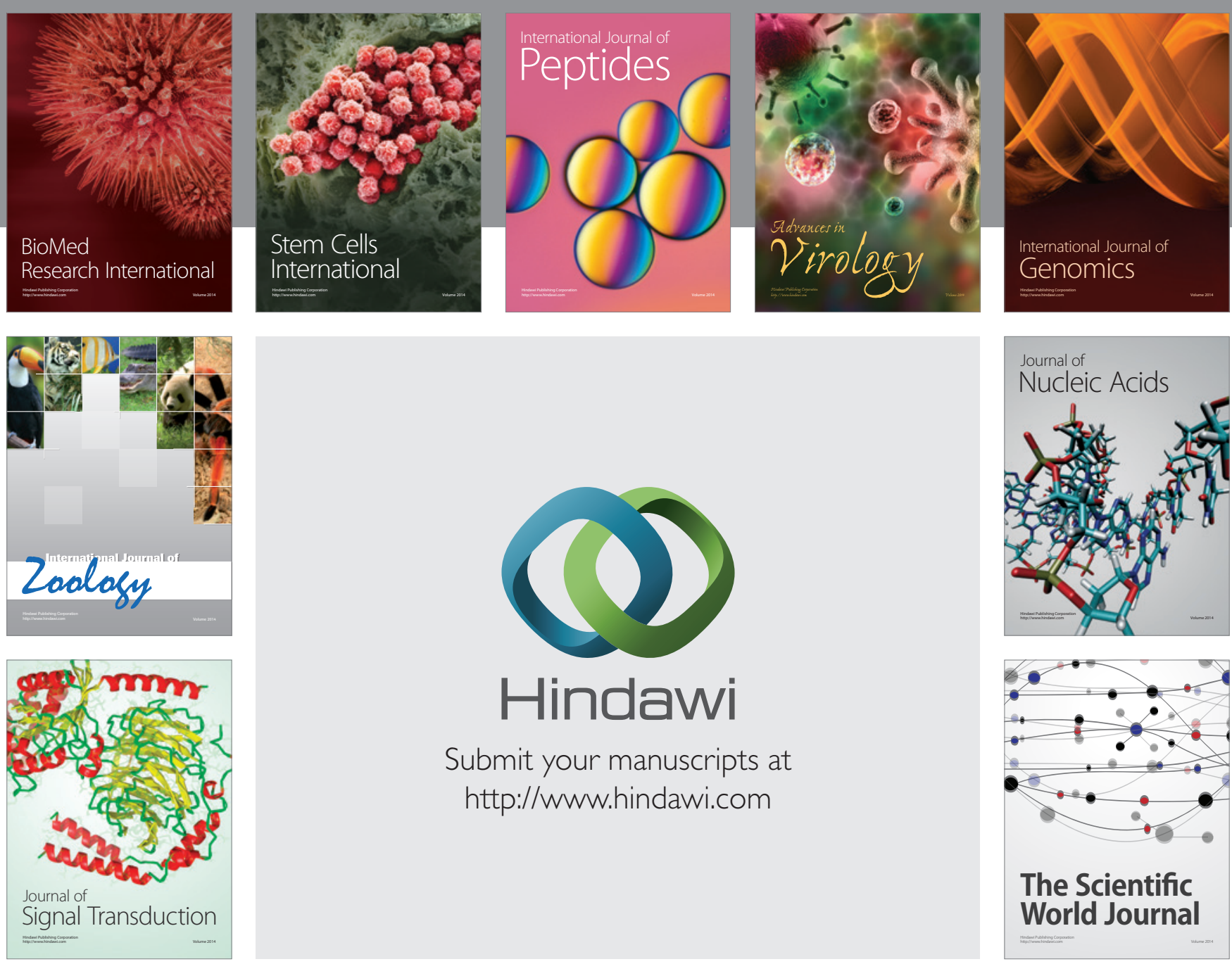

Submit your manuscripts at

http://www.hindawi.com
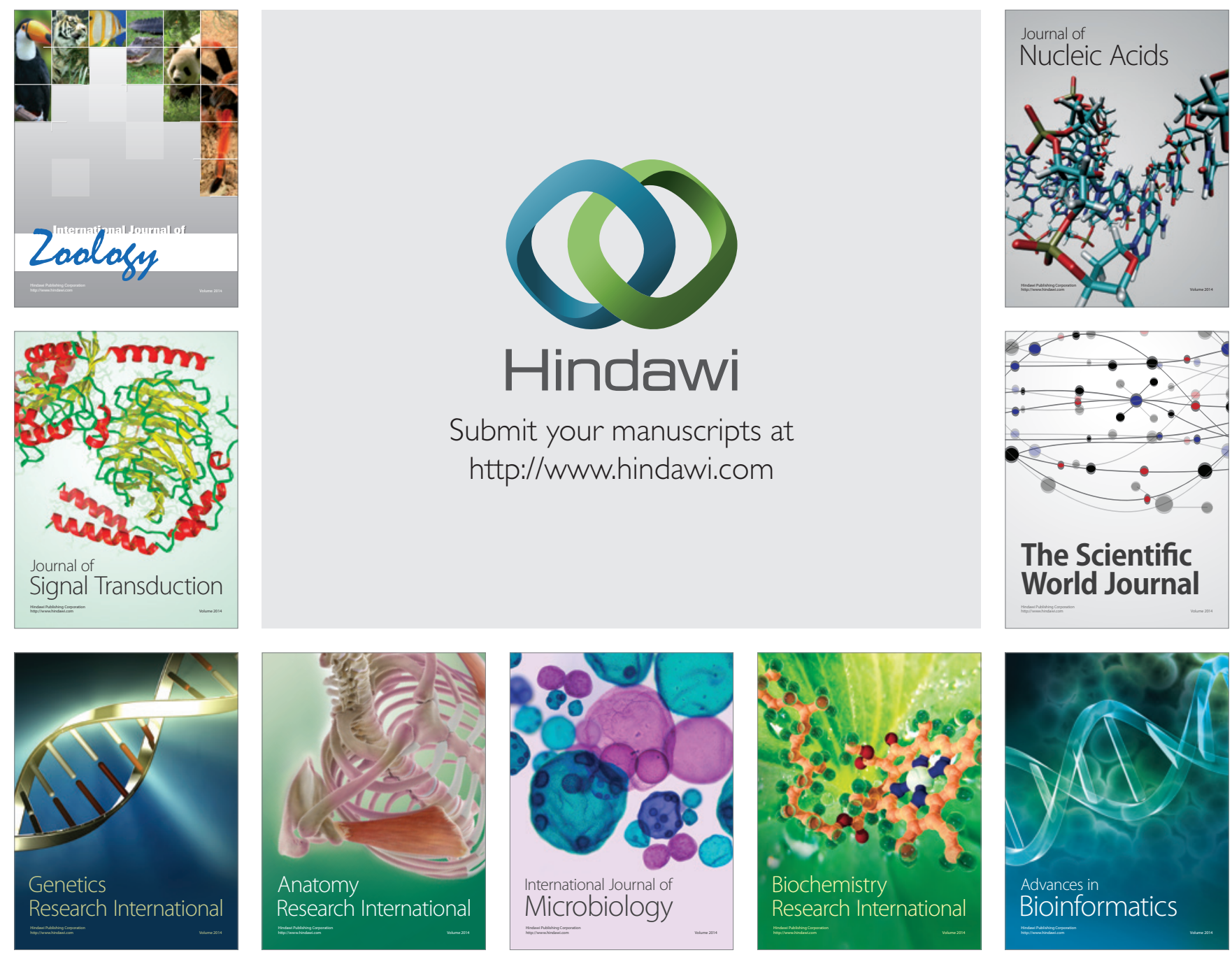

The Scientific World Journal
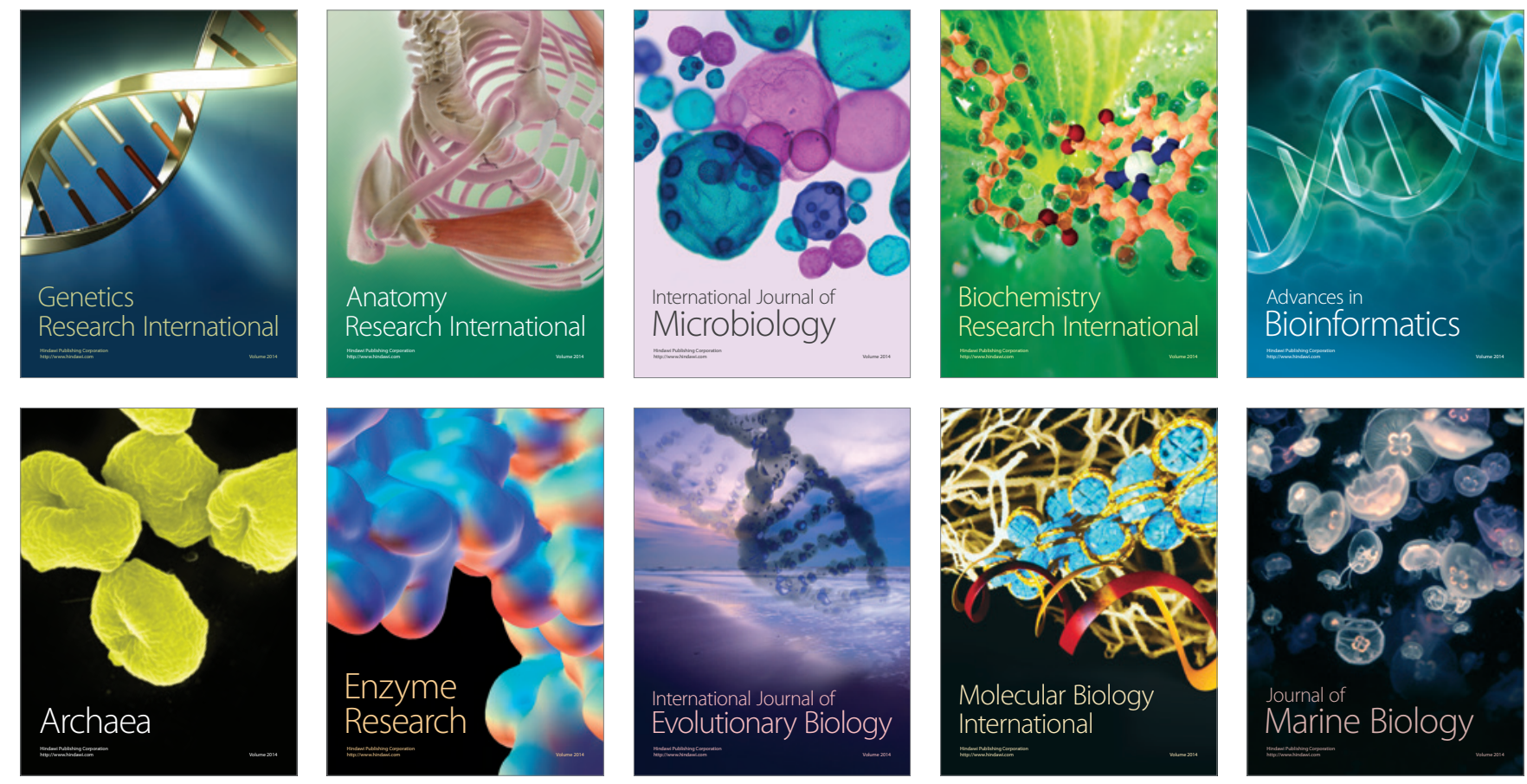